\title{
Signal Transducer and Activator of Transcription 3
}

National Cancer Institute

\section{Source}

National Cancer Institute. Signal Transducer and Activator of Transcription 3. NCI

Thesaurus. Code C28664.

Signal transducer and activator of transcription $3(770 \mathrm{aa}, \sim 88 \mathrm{kDa}$ ) is encoded by the human STAT 3 gene. This protein plays a role in cytokine signaling and gene expression. 